TITLE:

\title{
Application of human reliability analysis to nursing errors in hospitals(Abstract_要旨)
}

\author{
$\operatorname{AUTHOR(S):~}$ \\ Inoue, Kayoko
}

\section{CITATION:}

Inoue, Kayoko. Application of human reliability analysis to nursing errors in hospitals. 京 都大学, 2005, 博士(社会健康医学)

ISSUE DATE:

2005-03-23

URL:

http://hdl.handle.net/2433/145166

RIGHT: 


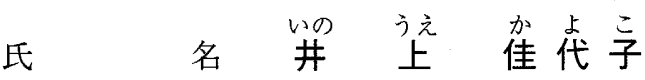

学位(専攻分野) 博士 (社会健康医学)

学位記番号 社 医 博第 4 号

学位授与の日付 平 成 17 年 3 月 23 日

学位授与の要件 学 位 規 則 第 4 条第 1 項 該 当

研究科・専攻医学研究科社会健康医学系専攻

学位論文題目 Application of human reliability analysis to nursing errors in hospitals

（病院に扔ける看護師のエラー分析への人間信頼性工学の適応）

論文調査委員教授今中雄一教授佐藤 俊 哉教 授吉原博幸

（緒言）人的エラーによる医療事故を未然に防止するためにはインシデントから学ぶことが重要であり，平成14年に厚生 労㗢省によりインシデントレポート収集が義務化された。しかし大量のインシデントレポートを分析する適切な手段がない。 本研究の目的は，インシデントレポートを利用してエラー分析とリスク評価を行なう model の開発である。エラーを誘発 する組織要因を検出し，リスクを定量的に把握し，対策を立案できる model を考案した。

（方法）この model は Incident data base と Management data baseの 2 本立てである。Incident data base は，インシデ ントレポートから抽出する 7 要因一(1)エラー連関鎖（2)業務 module ID (3)業務シフト (4)患者カテゴリー（5)薬歳要因 (6)重大性 score (7)潜在的危険性 score一で構成される。エラー連関鎖は, Error type code(E)-Direct threat code(D) - Indirect Threat code(IT) をEDIT model code table から選択し，4 桁の code で表す。業務 module ID は，医療業務が module の組合せで構築されると理解し，各 module につけた番号である。どの module ID によるエラーであるかを判断す る。重大性 score は患者に及んだ影響を 6 段階で表し, 潜在的危険性 score は今回は患者に身体的影響を及はさなかったが 将来的に及ぼす危険性を 5 段階で表す。Management data base は，量的リスク評価を行なうために，患者カテゴリー別入 院患者数，業務シフト別就労看護師数，患者別㧍よび看護師別に各業務 module 数を平日 3 日間と休日 1 日実測し， 1 年間 に換算したdata である。各業務 module のエラー率を年間の当該 module に㧍けるインシデント数と業務数から算出し, 業 務 module と他の 6 要素を種々に組合せたWeight も計算できるようにした。全国都市部の第 3 次病院 6 病院（平均病床数 610 床, 平均看護師数 370 名) に研究協力を得て看護部門（6病院の 1 年分のインシデントレポート 5,339 枚, 全業務 module 数63,294,144）にこの model を適用した。

（結果）model の validity と reliability を評価した。Incident data base の reliability 評価するために，各病院の risk management 委員会で最初に Incident data base を作成後, 全病院の 1 年分のインシデントレポート 5,339 枚の中からラン ダムに300枚を抜き取り 6 病院に振り分け，再分析を依頼した。7 要因は $80 \%$ 以上の確率で最初の data base と一致した。

また Management data baseの validity を評価するために, 標準業務数が一定の 2 業務 module の実測値を標準値と比較し, 近似することを確認した。業務 module のエラー率は 6 病院ともに，抒拈よそ $10^{-4}$ であった。エラーの背景にある 3 大組 織要因として, 規則非遵守, 労務管理不徹底, 医療行為の標準化不足が, それぞれWeight $826 \times 10^{-4}, 661 \times 10^{-4}, 495 \times$ $10^{-4}$ で同定された。

（結論）各病院の評価，病院間の比較，全病院に共通する問題点を的確に把握し，対策立案に結びつけることができる有 用な modelであり，医師，薬剤師等に関しても業務 moduleを明確化すれば活用できると考えられた。

\section{論 文 審查の結 果の 要 旨}

人的エラーによる医療事故を未然に防止するためにはインシデントから学ぶことが重要であり，平成14年に厚生労働省に 
よりインシデントレポート収集が義務化された。しかし大量のインシデントレポートを分析する適切な手段がない。そのた め, インシデントレポートを利用してエラー分析とリスク評価を行なう model を開発した。この model は Incident data base と Management data base からなる。Incident data base は, インシデントレポートから抽出する 7 要因一(1)エラー連 関鎖 (2)業務 module ID (3)業務シフト (4)患者カテゴリー (5)薬剤要因 (6)重大性 score (7)潜在的危険性 score一で構 成される。Management data base は，患者別，看護師別に業務数を計測したdataである。各業務のエラー率をインシデ ント数と業務数から算出し, 業務と他の 6 要素を種々に組合せた重みも計算できるようにした。全国 6 病院（平均病床数 610床, 平均看護師数370名）の看護部門で試行した。modelの validity と reliability ともに評価に耐えうるものであり，工 ラーを誘発する組織要因を検出し，リスクを定量的に把握し，対策立案に結びっく有用な手段になると考えられた。

以上の研究は, 医療事故の解明に貢献し，医療の質の向上に寄与するところが大きい。したがって本論文は，博士（社会 健康医学) の学位論文として価值あるものと認める。

なお, 本学位授与申請者は, 平成16年12月17日実施の論文内容とそれに関連した試問を受け, 合格と認められたものであ る。 